\title{
Isolation of a new toxic protease from a strain of Aeromonas salmonicida subspecies achromogenes
}

\author{
Bjarnheidur K. Gudmundsdottir ${ }^{1}$, Trevor S. Hastings ${ }^{2}$, Anthony E. Ellis ${ }^{2}$ \\ ${ }^{1}$ Institute for Experimental Pathology, Fish Disease Laboratory, University of Iceland, Keldur, 128 Reykjavik, Iceland \\ ${ }^{2}$ Department of Agriculture and Fisheries for Scotland, Marine Laboratory, PO Box 101, Victoria Road, Aberdeen AB9 8DB, \\ United Kingdom
}

\begin{abstract}
A new toxic protease was isolated from Aeromonas salmonicida subspecies achromogenes extracellular products (ECP). It was detected in 5 of 9 strains of the organism tested. The protease was purified by anion-exchange fast protein liquid chromatography (FPLC) on Mono Q HR 5/5, and FPLC gel filtration on Superose $12 \mathrm{HR} 10 / 30$. The $\mathrm{LD}_{50}$ of the purified protease for juvenile Atlantic salmon Salmo salar $\mathrm{L}$. was $0.03 \mu \mathrm{g}$ protein $\mathrm{g}^{-1}$ fish. The molecular weight of the protease was estimated to be 20 $\mathrm{kD}$ by SDS-polyacrylamide gel electrophoresis (SDS-PAGE) and it possessed 2 isoelectric points (pIs) of 6.2 and 6.4. The protease was completely inhibited by EDTA indicating it to be a metallo-protease
\end{abstract}

\section{INTRODUCTION}

The Gram-negative bacterium Aeromonas salmonicida has been known as a fish pathogen for over 90 yr but its virulence mechanisms are still incompletely understood.

The species Aeromonas salmonicida is classified into 3 subspecies: A. salmonicida subsp. salmonicida, $A$. salmonicida subsp. masoucida, and $A$. salmonicida subsp. achromogenes (Popoff 1984). Subspecies salmonicida is the causative agent of furunculosis in salmonid fish and is often referred to as the typical strain, with subspecies masoucida and achromogenes as the atypical strains, causing atypical furunculosis or ulcerative inflammations of skin and muscles (Austin \& Austin 1987. Wichardt 1983). A. salmonicida subsp. masoucida has only been isolated from Japanese salmon (Popoff 1984), but subsp. achromogenes has been isolated both from salmonid and non-salmonid fish (Austin \& Austin 1987).

The virulence mechanisms of Aeromonas salmonicida subsp. salmonicida have been investigated by many workers. The presence of an additional protein layer (A-protein) on the outer surface of the bacterium has been related to virulence (Udey \& Fryer 1978, Trust et al. 1980, Kay et al. 1981, Evenberg \& Lugtenberg 1982). However, some workers have described virulent strains lacking the A-layer (Johnson et al. 1985, Ward et al. 1985, Adams et al. 1988, Ellis et al. 1988a). Extracellular products (ECP) of the bacterium have been associated with the pathology of furunculosis and are lethal to salmonid fish when administered parenterally (Munro et al. 1980, Cipriano et al. 1981, Ellis et al. 1981). A variety of ECP activities of subsp. salmonicida have been described including glycerophospholipid-cholesterol acyltransferase (GCAT) (Buckley et al. 1982, Lee \& Ellis 1990), a leucocytolysin (Fuller et al. 1977), haemolysins (Titball \& Munn 1981, Hastings \& Ellis 1985, Fyfe et al. 1987. Nomura et al, 1988, Lee \& Ellis 1990) and proteases (Shieh \& McLean 1975, Mellergaard 1983, Tajima et al. 1984, Hastings \& Ellis 1985, Fyfe et al. 1986, Fyfe et al. 1987). Some strains have been reported as producing 2 distinct proteases, a caseinolytic serine protease (P1) and a gelatinolytic metallo-protease (P2) (Sheeran \& Smith 1981, Rockey et al. 1988). The serine protease (molecular weight $70 \mathrm{kD}$ ) has been considered to be an important virulence factor of $A$. salmonicida (Sakai $1985 \mathrm{a}, \mathrm{b}$ ). It has been suggested that extracellular protease may be a protective antigen against furunculosis (Sakai 1985c, Shieh 1985, Ellis et al. 1988b, c, Hastings \& Ellis 1988). A haemolytic toxin lethal to salmonid fish has been isolated from $A$. salmonicida subsp. salmonicida ECP (Nomura et al. 1988) and has been identified as GCAT complexed with lipopolysaccharide (Lee \& Ellis 1990).

Little has been published regarding Aeromonas salmonicida subsp. achromogenes extracellular virulence 
factors. Pol et al. (1980) reported that crude ECP of one atypical strain was lethal for carp. Toxicity of ECP was heat-labile but the nature of the toxin(s) was not determined. Hastings \& Ellis (1985) reported a difference in production of haemolytic and proteolytic activities by 5 isolates of A. salmonicida subsp. salmonicida and 1 isolate of $A$. salmonicida subsp. achromogenes. In contrast to the typical isolates, the achromogenic isolate did not produce detectable haemolysin and its caseinase had properties compatible with those of a metallo-protease. Evenberg et al. (1988) reported vaccination results where immunity against $A$. salmonicida subsp. achromogenes ECP was of prime importance, although the nature of the protective antigen(s) was not reported.

The present study deals with the purification and properties of a new lethal toxic proteolytic enzyme produced by Aeromonas salmonicida subsp. achromogenes.

\section{MATERIALS AND METHODS}

Bacterial strains. Aeromonas salmonicida strains used in this study are described in Table 1. The strains were classified as $A$. salmonicida subsp. salmonicida and achromogenes on the basis of biochemical reactions and antibiograms. All subsp. achromogenes strains used in the study were differentiated from subsp. salmonicida strains by the following characteristics: The former strains produced indole and acid from sucrose; failed to produce gas from glucose and to degrade aesculine; were resistant to the antibiotics ampicillin and cefaloridin; and showed no or delayed production of brown pigment.

The subsp. salmonicida strain used was nonaggregating, but all subsp. achromogenes isolates were autoaggregating.

Stock cultures were stored in tryptone soya broth (TSB, Oxoid) $+10 \%$ glycerol at $-20^{\circ} \mathrm{C}$. Bacteria were routinely cultured on brain heart infusion agar (BHI, Oxoid $+1 \%$ Oxoid bacteriological agar No. 1) at $22^{\circ} \mathrm{C}$.

Extracellular products (ECP). ECP were produced by the cellophane overlay method as described by Munro et al. (1980) using BHIA at $22^{\circ} \mathrm{C}$. After $48 \mathrm{~h}$ incubation, the culture was washed from the cellophane with a minimal volume of phosphate-buffered saline, PBS (Dulbecco's $\mathrm{Ca}^{++}$and $\mathrm{Mg}^{++}$free; Gibco) pH 7.2 and centrifuged. The supernatant (ECP) was filtered (Millipore, $0.22 \mu \mathrm{m}$ ) and stored at $-20^{\circ} \mathrm{C}$.

Protein determination. Protein concentration was determined by the method of Bradford (1976) using bovine serum albumin as a standard.

Proteolytic assays. Proteolytic activity was determined in the following way: $2.4 \mathrm{ml}$ PBS were added to $25 \mathrm{mg}$ hide powder azure (HPA, Calbiochem). The enzyme $(0.1 \mathrm{ml})$ was added and incubated at $37^{\circ} \mathrm{C}$ for $15 \mathrm{~min}$. The reaction was stopped by the addition of 2.5 $\mathrm{ml} \mathrm{10 \% (w/v)} \mathrm{trichloroacetic} \mathrm{acid} \mathrm{(TCA).} \mathrm{After} \mathrm{centrifu-}$ gation, the absorbance of the supernatant was measured at $595 \mathrm{~nm}\left(\mathrm{~A}_{595}\right)$ against substrate blanks. One unit of proteolytic activity was equivalent to a change of $0.01 \mathrm{~A}_{595}$ units.

Gelatinase and caseinase activities. Hydrolysis of gelatin and casein was detected by a radial diffusion method (Hastings \& Ellis 1985). Caseinase and gelatinase activity was determined from a standard curve using trypsin (bovine pancreas type III, Sigma). One unit of caseinase or gelatinase activity was defined as that which produced a zone of clearing equal in area to that produced by $1 \mu \mathrm{g}$ trypsin.

Haemolytic titration. Haemolytic activity was determined as previously described (Hastings \& Ellis 1985) using rainbow trout, sheep, and horse erythrocytes. Blood was collected in Alsevers solution and the red blood cells (RBCs) were washed 3 times in PBS and resuspended to $1 \%(\mathrm{v} / \mathrm{v})$ in PBS. Haemolytic activity was determined by diluting $100 \mu \mathrm{l}$ of sample in 2-fold steps in PBS, adding $100 \mu \mathrm{l}$ RBC suspension, and

Table 1. Bacterial strains investigated in this study

\begin{tabular}{|c|c|c|c|}
\hline Isolate number & $\begin{array}{l}\text { A. salmonicida } \\
\text { subspecies }\end{array}$ & Host species & Country \\
\hline MT004 & salmonicida & Atlantic salmon Salmo salar & Scotland \\
\hline Lon/82 & achromogenes & Atlantic salmon Salmo salar & Iceland \\
\hline $265 / 87$ & achromogenes & Atlantic salmon Salmo salar & Iceland \\
\hline Fell & achromogenes & Sea trout Salmo trutta & Faeroe Islands \\
\hline $23 / 87$ & achromogenes & Atlantic salmon Salmo salar & Iceland \\
\hline $17 / 87$ & achromogenes & Atlantic salmon Salmo salar & Iceland \\
\hline Eldi/80 & achromogenes & Atlantic salmon Salmo salar & Iceland \\
\hline 3.111 & achromogenes & Goldfish Carassius auratus & USA \\
\hline V75/93 & achromogenes & Carp Cyprinus carpio & Yugoslavia \\
\hline $16 / 76$ & achromogenes & Rudd Scardinius erythrophthalmus & England \\
\hline
\end{tabular}


incubating at $22^{\circ} \mathrm{C}$ for $20 \mathrm{~h}$. The dilution of sample which caused $50 \%$ haemolysis was defined to contain one haemolytic unit (HU).

Phospholipase assay. Phospholipase activity was determined by applying $20 \mu \mathrm{l}$ sample into wells cut in $1 \%(\mathrm{w} / \mathrm{v})$ agarose in PBS containing $1 \% \mathrm{~L}-\alpha$ lecithin (Sigma) and incubating at $22^{\circ} \mathrm{C}$ for $48 \mathrm{~h}$. Clearing around the well indicated a positive phospholipase reaction.

Cytotoxicity assay. Cytotoxic activity of ECP 265/87 and the toxic protease was determined using cultured rainbow trout gonad cells (RTG-2). Confluent cell monolayers were prepared in 96-well flat-bottom microtiter plates containing $200 \mu \mathrm{l}$ Glasgow modification of Eagles medium (GMEM, Flow) supplemented with antibiotics, tryptose phosphate broth, $8 \mathrm{mM}$ glutamine, and $10 \%$ foetal calf serum. Medium was aspirated from test wells containing RTG-2 cells. Half of the wells received $100 \mu \mathrm{l}$ of GMEM medium $+2 \%$ serum and the other half received GMEM without serum. Then $40 \mu$ l of enzyme solution, or PBS as a control, were added to wells and the reaction systems incubated at $15^{\circ} \mathrm{C}$ for $48 \mathrm{~h}$. The cells were examined microscopically for cytotoxic effects.

Toxicity test. Lethal activity was estimated by intraperitoneal injection of juvenile Atlantic salmon Salmo salar L. (mean weight: $40 \mathrm{~g}$ ) with $0.1 \mathrm{ml}$ of protease, diluted in PBS. Control fish were injected with $0.1 \mathrm{ml}$ PBS. Mortality was recorded after $24 \mathrm{~h}$. $\mathrm{LD}_{50}$ was calculated by the method of Reed \& Muench (1938).

Inhibition studies. The effects of ethylene diamine tetraacetic acid (EDTA) and phenyl methyl sulfonyl fluoride (PMSF) on the proteolytic activity were examined. Enzyme inhibition tests were performed by mixing $50 \mu \mathrm{l}$ of purified enzyme and $50 \mu \mathrm{l}$ freshly prepared $20 \mathrm{mM}$ EDTA in PBS or $25 \mathrm{mM}$ PMSF in propan-2-ol. Reaction mixtures were incubated at $22^{\circ} \mathrm{C}$ for $10 \mathrm{~min}$ prior to assay. Controls contained the solvents alone.

SDS-polyacrylamide gel electrophoresis. Sodium dodecyl sulfate polyacrylamide gel electrophoresis (SDS-PAGE) for the molecular weight determination and to check the purity of fractions was carried out as described by Laemmli (1970), using $12.5 \%$ gels. Pharmacia low molecular weight (LMW) standards were used as marker proteins. Samples were incubated for $10 \mathrm{~min}$ at $100^{\circ} \mathrm{C}$ with sample buffer $(1: 2 \mathrm{v} / \mathrm{v})$ comprised of $4 \%$ SDS and $5 \%$ 2-mercaptoethanol in Tris- $\mathrm{HCl} \mathrm{pH}$ 8.0. Protein bands were visualized by silver staining using Bio-Rad silver stain kit according to the manufacturer's instructions.

Purification of a toxic protease. Strain 265/87 ECP $(5 \mathrm{ml})$ was desalted on a Sephadex G-25M (Pharmacia PD-10) column. Proteins were eluted with distilled water and applied to a Mono Q HR 5/5 anion-exchange column (Pharmacia) in a Pharmacia fast protein liquid chromatography (FPLC) apparatus, Proteins were eluted using a gradient of 0 to $1 \mathrm{M} \mathrm{NaCl}$ in $20 \mathrm{mM}$ Tris (hydroxymethyl) methylamine $\mathrm{pH} 7.7$ at a flow rate of $1 \mathrm{ml} \mathrm{min} \mathrm{m}^{-1}$ and $1.0 \mathrm{ml}$ fractions were collected. Elution profiles were recorded with an UV absorbance monitor at $280 \mathrm{~nm}\left(\mathrm{~A}_{280}\right)$. Total protein, toxicity, and proteolytic, haemolytic, cytotoxic and phospholipase activities were determined in peak fractions. Toxic fractions were examined by SDS-PAGE for protein purity.

Toxic fractions were run separately on a Superose 12 HR 10/30 gel filtration column (Pharmacia) in the FPLC system. Proteins were eluted with PBS pH 7.2 at a flow rate of $0.5 \mathrm{ml} \mathrm{min}^{-1}$. Fractions $(0.5 \mathrm{ml})$ were collected and tested for purity and activities as described above. The column was calibrated with the following molecular weight marker proteins: bovine serum albumin, soybean trypsin inhibitor, and $\alpha$-lactalbumin under the same running conditions as described above.

Isoelectric focusing. Isoelectric focusing (IEF) was done in Pharmacia PhastSystem PhastGel IEF 3-9. Pharmacia standards $\mathrm{pH} 3$ to 10 were used to determine the $\mathrm{pH}$ gradient. Gels were run for $500 \mathrm{Vh}$ at $15^{\circ} \mathrm{C}$ and silver stained.

Preparation of rabbit antisera. Rabbit antiserum for formalin-inactivated ECP (f-ECP) of isolate 265/87 was prepared as follows: ECP was toxoided by adding formalin [to give a final concentration of $1.2 \%(\mathrm{w} / \mathrm{v})$ formaldehydel and incubating for $7 \mathrm{~d}$ at $22^{\circ} \mathrm{C}$. A rabbit was injected subcutaneously with f-ECP $(750 \mu \mathrm{g}$ protein) emulsified with Freund's complete adjuvant (Difco). A booster injection of f-ECP ( $2 \mathrm{mg}$ protein) without adjuvant was administered after $28 \mathrm{~d}$. The rabbit was bled $20 \mathrm{~d}$ later and serum extracted and stored at $-20^{\circ} \mathrm{C}$ (R-anti-f-ECP 265/87).

Western blotting. Samples were separated by SDSPAGE in 4 to $30 \%$ gradient polyacrylamide gels (Pharmacia $L K B$ ) at $150 \mathrm{~V}$ for $170 \mathrm{~min}$ at $10^{\circ} \mathrm{C}$. SDS-PAGE fractionated antigens were transferred to nitrocellulose by electrophoresis $(30 \mathrm{~V}, 16 \mathrm{~h})$. Transfer buffer was comprised of $25 \mathrm{mM}$ Tris- $\mathrm{HCl}(\mathrm{pH} 8.3), 192 \mathrm{mM}$ glycine, and $20 \%$ methanol. Following transfer, nitrocellulose membranes were either stained for total protein using colloidal gold (Aurodye, Janssen) or blocked for 1 h with $3 \%$ gelatin prior to immunostaining. For Western blotting, gelatin-blocked membranes were washed $(2 \times 5 \mathrm{~min})$ in tris-buffered saline $\mathrm{pH} 7.5$ containing $0.05 \%$ Tween 20 (TTBS), and incubated for $1 \mathrm{~h}$ in control or immune rabbit serum diluted 1:1000. Antibody dilution buffer was TTBS containing $1 \%$ gelatin. After further washing in TTBS, membranes were incubated for $1 \mathrm{~h}$ with goat anti-rabbit IgG-alkaline phosphatase conjugate (Bio-Rad) diluted 1:3000. Bands were visualised by incubating membranes in $0.1 \mathrm{M}$ carbonate buffer pH 9.8 containing $0.3 \mathrm{mg} \mathrm{ml}^{-1} \mathrm{p}$-nitro 
blue tetrozolium chloride and $0.15 \mathrm{mg} \mathrm{ml}^{-1} 5$-bromo-4chloro-3 inoldyl phosphate toluidine salt.

Relationship between cultivation time and production of protease. One $\mathrm{ml}$ of a fresh culture of strain 265/ 87 was inoculated into $100 \mathrm{ml} \mathrm{BHI}$ broth in a $200 \mathrm{ml}$ Erlenmeyer flask and incubated at $22^{\circ} \mathrm{C}$ on a rotary shaker for $73 \mathrm{~h}$. Samples were taken periodically during incubation. For colony-forming unit (cfu) counts, $0.1 \mathrm{ml}$ samples of 10 -fold serial dilutions were spread onto blood agar plates and incubated at $22^{\circ} \mathrm{C}$ for $48 \mathrm{~h}$. For detection of proteolytic activity $0.5 \mathrm{ml}$ of the culture was centrifuged and proteolytic activity of the supernatant determined in a caseinase assay.

\section{RESULTS}

\section{Purification of protease}

ECP proteins eluted as several peaks in anionexchange FPLC, with proteolytic activity eluting as a single peak between 0.09 and $0.20 \mathrm{M} \mathrm{NaCl}$ (Fig. 1). Peak fractions 10 and 11 were further separated by gel filtration FPLC. The elution profile revealed one major and one minor protein peak (Fig. 2). Proteolytic activity was detected only in the major peak with highest activity in fraction 33. Total recovery of protease activity following gel filtration was $11.7 \%$ and the relative purification was 17 -fold (Table 2).

\section{Toxicity}

Intraperitoneal injection of juvenile salmon with samples of elution peaks from FPLC anion-exchange column showed lethal toxicity only in fractions 9,10 and 11 indicating coelution with proteolytic activity (Fig. 1). Protease-containing fractions $33 / 10$ and $33 / 11$ (fractions 33 from FPLC gel filtration) were lethal when injected into salmon (Table 3). The $24 \mathrm{~h} \mathrm{LD}_{50}$ value of the protease was $0.03 \mu \mathrm{g}$ protein $\mathrm{g}^{-1}$ fish

\section{Purity, molecular weight and isoelectric point of protease}

SDS-polyacrylamide gel electrophoresis (SDSPAGE) of fractions from the FPLC anion-exchange column showed that the lethal fractions 9, 10, and 11 all contained the same protein band but also other bands (Fig. 3). Gel filtration of fractions 10 and 11 produced one major peak with protease and another minor peak without detectable protease activity (Fig. 2). Analysis of protein fractions from the major peak by SDS-PAGE showed one protein band in fraction number 33 with a

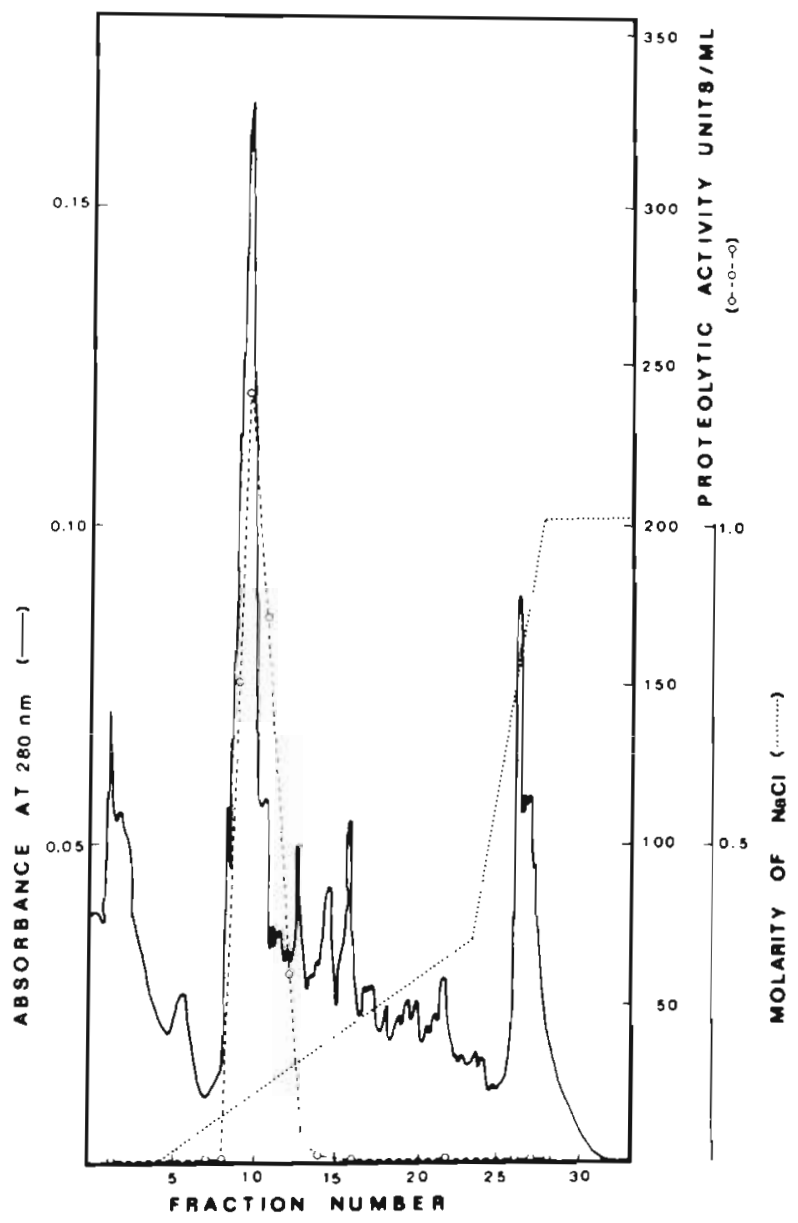

Fig. 1. Aeromonas salmonicida subsp. achromogenes strain 265/87. Mono Q HR 5/5 FPLC anion-exchange chromatography of extracellular products (ECP)

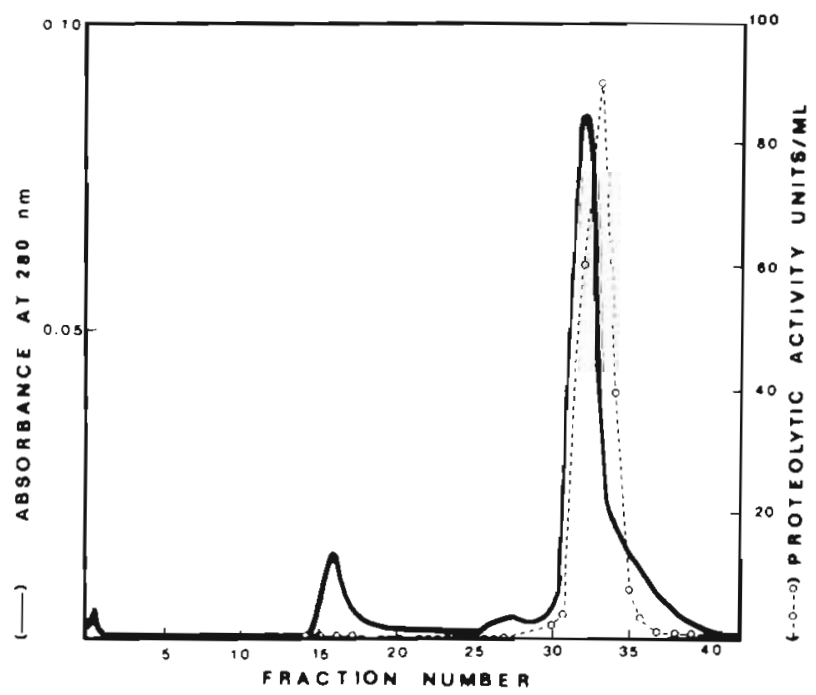

Fig. 2. Aeromonas salmonicida subsp. achromogenes strain 265/87 Superose 12 HR 10/30 FPLC gel filtration chromatography of fraction 10 from Mono $Q$ HR 5/5 FPLC anionexchange chromatography of ECP 
Table 2. Purification of Aeromonas salmonicida subsp. achromogenes toxic protease

\begin{tabular}{|c|c|c|c|c|c|c|c|}
\hline Purification step & $\begin{array}{l}\text { Fraction } \\
\text { number }\end{array}$ & $\begin{array}{l}\text { Volume } \\
\qquad(\mathrm{ml})\end{array}$ & $\begin{array}{l}\text { Total protein } \\
\text { (mg) }\end{array}$ & $\begin{array}{l}\text { Proteolytic } \\
\text { units }\end{array}$ & $\begin{array}{l}\text { Specific activity } \\
\text { (units } \mathrm{mg}^{-1} \text { ) }\end{array}$ & $\begin{array}{c}\text { Recovery } \\
(\%)\end{array}$ & $\begin{array}{l}\text { Relative } \\
\text { purification }\end{array}$ \\
\hline $\begin{array}{l}\text { 1. PD-10 gel } \\
\text { filtration }\end{array}$ & & 7.0 & 2.625 & 770 & 293.3 & 100 & 1 \\
\hline $\begin{array}{l}\text { 2. Mono Q HR } 5 / 5 \\
\text { anion-exchange }\end{array}$ & $10+11$ & 2.0 & 0.602 & 410 & 681.1 & 53.2 & 2.3 \\
\hline $\begin{array}{l}\text { 3. Sup. } 12 \text { HR } 10 / 30 \\
\text { gel filtration }\end{array}$ & $33 / 10^{d}+33 / 11$ & 1.0 & 0.018 & 90 & 5000.0 & 11.7 & 17.0 \\
\hline
\end{tabular}

Table 3. Salmo salar. Lethal toxicity of Aeromonas salmonicida subsp. achromogenes protease to Atlantic salmon. Mean body weight of fish was $40 \mathrm{~g}$

\begin{tabular}{|ccc|}
\hline $\begin{array}{c}\text { Dose } \mu \mathrm{g} \\
\text { protein fish }\end{array}$ & $\begin{array}{c}\text { No. of } \\
\text { fish injected }\end{array}$ & $\begin{array}{c}\text { Mortality within } \\
24 \mathrm{~h}\end{array}$ \\
\hline 3.60 & 2 & 2 \\
2.40 & 5 & 5 \\
1.80 & 5 & 4 \\
0.90 & 5 & 1 \\
0.45 & 5 & 0 \\
$\mathrm{LD}_{50}=0.03 \mu \mathrm{g} \mathrm{g}^{-1}$ fish & \\
\hline
\end{tabular}

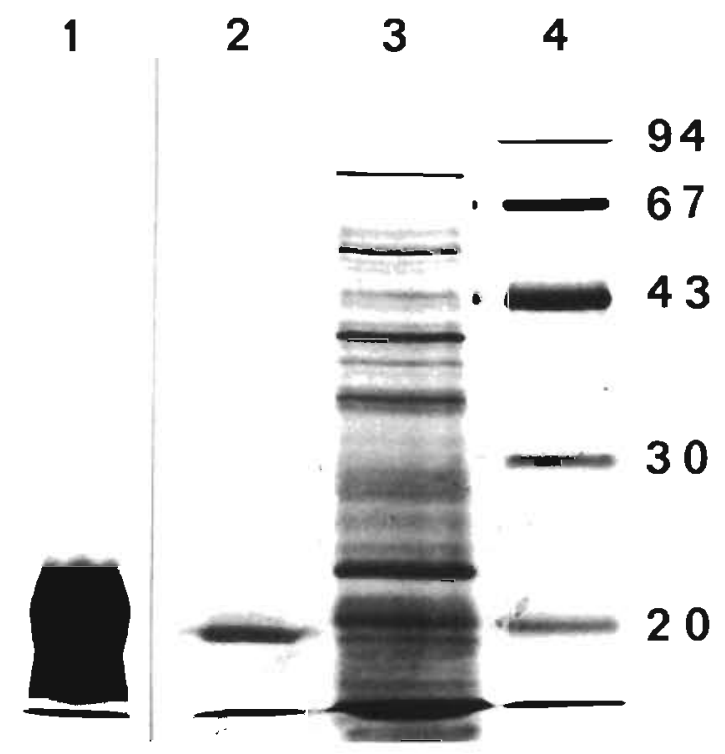

Fig. 3. Aeromonas salmonicida subsp. achromogenes strain $265 / 87$. Purification of extracellular protease, monitored by SDS-PAGE. Protein loadings are listed in parentheses. Lane 1: fraction 11 from ion-exchange chromatography $(6.02 \mu \mathrm{g})$; lane 2: purified protease, fraction 33/11 following gel filtration $(0.9$ $\mu \mathrm{g})$; lane 3: crude ECP $(3.75 \mu \mathrm{g})$; lane 4: molecular weight marker proteins. Molecular weights are indicated in $\mathrm{kD}$
MW of $20 \mathrm{kD}$. Two faint bands (not seen in fraction 11, from which fraction 33 originated) were also present in fraction 33 (Fig. 3). The same faint bands were seen in blank runs (data not shown), indicative of artifacts in the gel system previously seen in this MW range $(68$ kD, $54 \mathrm{kD}$ ) (Tasheva \& Dessev 1983).

Calibration of the gel filtration column with molecular weight standards resulted in soybean trypsin inhibitor (MW $20 \mathrm{kD}$ ) eluting in fraction 27. The pure native protease was eluted in fraction 33, showing a molecular weight of less than $20 \mathrm{kD}$ by gel filtration.

The results from the gel filtration coupled with SDSPAGE indicate the protease to be a monomeric polypeptide in the native state. Fraction 33 showed both proteolytic activity and lethal toxicity (Fig. 2, Table 2), indicating a pure toxic protease.

Two isoelectric forms of the purified protease were detected by isoelectric focusing. The isoelectric points were pI 6.2 and 6.4 (Fig. 4).

\section{Studies of protease activity}

The protein concentration of fraction 33/11, the pure toxic protease, was $18 \mu \mathrm{g} \mathrm{m} \mathrm{m}^{-1}$. The proteolytic activity of the pure toxic protease was 90 units $\mathrm{ml}^{-1}$ in a HPA assay. Caseinase and gelatinase activities were determined to be 40 and 5 units $\mathrm{ml}^{-1}$, respectively (Table 4a).

Neither the ECP from Aeromonas salmonicida subsp. achromogenes strain $265 / 87$ nor the pure toxic protease was haemolytic against rainbow trout, sheep, or horse erythrocytes and neither possessed phospholipase activity (ECP of $A$. salmonicida subsp. salmonicida strain MT004 was used as a positive control). Cytotoxic activity against rainbow trout gonad cells (RTG-2) was observed with ECP (HPA proteolytic activity, 170 units $\mathrm{ml}^{-1}$ ) in GMEM medium without serum, but cells incubated with ECP in the presence of $2 \%$ foetal calf serum or with purified protease (170 units $\mathrm{ml}^{-1}$ ) (with and without calf serum) were unaffected. This indicates the 


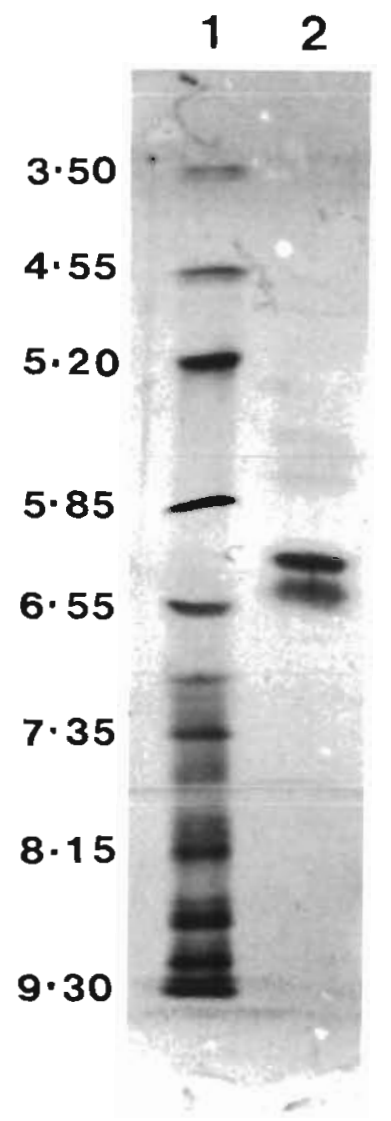

Fig. 4. Aeromonas salmonicida subsp. achromogenes strain 265/87. Isoelectric focusing of extracellular protease. Lane 1: pI marker proteins; lane 2: purified protease

presence of a cytotoxin in ECP that is inhibited by serum. It also indicates that the protease was not cytotoxic.

\section{Effect of inhibitors}

Proteolytic activity of the toxic protease was completely inhibited by EDTA but PMSF had no effect, indicating this enzyme to be a metallo-protease (Table $4 \mathrm{a}$ ). Inhibition of proteolytic activity of ECP from the different Aeromonas salmonicida isolates by EDTA and PMSF is shown in Table $4 \mathrm{~b}$. Only 0 to $32 \%$ of the protease activity in the ECP of atypical strains resisted treatment with EDTA but most of the protease activity (86 to $100 \%$ ) resisted treatment with PMSF. Conversely, the proteolytic activity of the ECP of the typical strain (MT004) was mainly PMSF sensitive.

\section{Relationship between cultivation time and production of protease}

Protease activity was present in the supernatant from an early phase of exponential growth and increased at the same rate as the increase in cell numbers up to $24 \mathrm{~h}$ of culture. Thereafter, it increased at a slower rate than the cell counts (Fig. 5).

\section{Western blotting}

Antibody in R-anti-f-ECP $265 / 87$ serum to the $20 \mathrm{kD}$ band detected the band in the ECP of 5 of 9 Aeromonas salmonicida subsp. achromogenes isolates tested (Fig. 6 , lanes 2, 3, 4, 6, and 7). All ECP's showing the $20 \mathrm{kD}$ band possessed a metallo-protease activity (Table $4 \mathrm{~b}$ ). ECP of the typical strain MT004 possessing a high serine-protease activity (Table 4 b) did not show a 20 $\mathrm{kD}$ band (Fig. 6, lane 1).

\section{DISCUSSION}

The extracellular protease isolated in this study from Aeromonas salmonicida subsp. achromogenes has not previously been described. The enzyme is caseinolytic and gelatinolytic, has a molecular weight of $20 \mathrm{kD}$ and pIs of 6.2 and 6.4 , and its activity is completely inhibited by the metal ion chelator EDTA, indicating it to be a metallo-protease. These properties distinguish it from the 2 extracellular proteases (P1 and P2) of $A$. salmonicida subsp. salmonicida which have previously been described. The P1 protease is a caseinolytic and gelatinolytic serine protease of molecular weight $70 \mathrm{kD}$ and pI 5.6 (Tajima et al. 1984, Fyfe et al. 1986, Hastings \& Ellis 1988, Price et al. 1989), whereas the P2 protease is a gelatinolytic (but not caseinolytic) metallo-protease

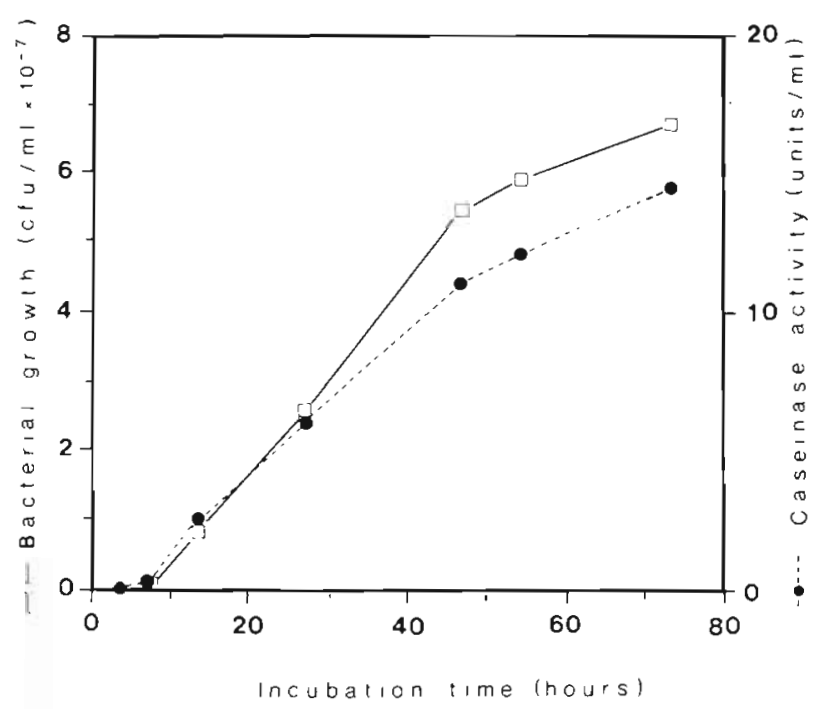

Fig. 5. Aeromonas salmoniciad subsp. achromogenes strain 265/87. Relationship between growth and the production of extracellular protease 
Table 4a. Proteolytic activities of the purified $20 \mathrm{kD}$ protease. EDTA: ethylene diamine tetraacetic acid; PMSF: phenyl methyl sulfonyl fluoride

\begin{tabular}{|c|c|c|c|c|c|}
\hline \multirow[t]{2}{*}{$\begin{array}{l}\text { Protein concentration } \\
\qquad\left(\mu \mathrm{g} \mathrm{ml} \mathrm{m}^{-1}\right)\end{array}$} & \multirow[t]{2}{*}{$\begin{array}{c}\text { Caseinase } \\
\text { (units } \mathrm{ml}^{-1} \text { ) }\end{array}$} & \multirow[t]{2}{*}{$\begin{array}{c}\text { Gelatinase } \\
\text { (units } \mathrm{ml}^{-1} \text { ) }\end{array}$} & \multirow[t]{2}{*}{$\begin{array}{l}\text { Proteolytic (HPA) } \\
\text { (units } \mathrm{mg}^{-1} \text { protein) }\end{array}$} & \multicolumn{2}{|c|}{$\begin{array}{c}\text { Percentage HPA activity remaining } \\
\text { after treatment with: }\end{array}$} \\
\hline & & & & EDTA & PMSF \\
\hline 18 & 40 & 5 & 90 & 0 & 100 \\
\hline
\end{tabular}

Table 4b. Proteolytic activities of ECP from different Aeromonas salmonicida isolates

\begin{tabular}{|c|c|c|c|c|c|}
\hline \multirow[t]{2}{*}{$\begin{array}{c}\text { ECP } \\
\text { number }\end{array}$} & \multirow[t]{2}{*}{$\begin{array}{l}\text { Isolate } \\
\text { number }\end{array}$} & \multirow[t]{2}{*}{$\begin{array}{l}\text { Protein concentration } \\
\qquad\left(\mu \mathrm{g} \mathrm{ml} \mathrm{I}^{-1}\right)\end{array}$} & \multirow[t]{2}{*}{$\begin{array}{l}\text { Proteolytic activity } \\
\text { (units } \mathrm{mg}^{-1} \text { protein) }\end{array}$} & \multicolumn{2}{|c|}{$\begin{array}{c}\text { Percentage activity remaining } \\
\text { after treatment with }\end{array}$} \\
\hline & & & & EDTA & PMSF \\
\hline 1 & MT004 & 710 & 718 & 85 & 5 \\
\hline 2 & Lon/82 & 275 & 36 & 0 & 100 \\
\hline 3 & $265 / 87$ & 375 & 293 & 32 & 86 \\
\hline 4 & FeII & 980 & 143 & 22 & 88 \\
\hline 5 & $23 / 87$ & 400 & 10 & 0 & 0 \\
\hline 6 & $17 / 87$ & 550 & 165 & 0 & 100 \\
\hline 7 & Eldi/80 & 500 & 6 & 0 & 100 \\
\hline 8 & 3.111 & 600 & 0 & 0 & 0 \\
\hline 9 & V75/93 & 425 & 5 & 0 & 0 \\
\hline 10 & $16 / 76$ & 200 & 0 & 0 & 0 \\
\hline
\end{tabular}

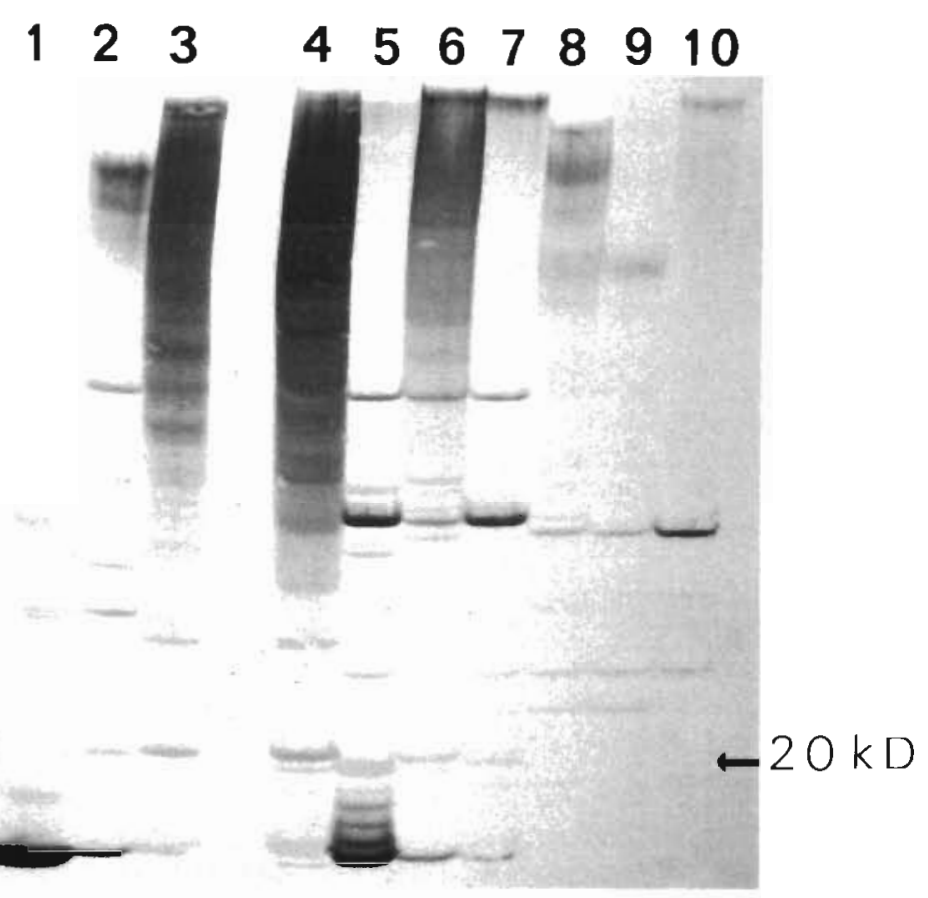

Fig. 6. Detection of antibody to Aeromonas salmonicida subsp. achromogenes extracellular $20 \mathrm{kD}$ protease by Western blotting in ECP of: 1, MTO04; 2, Lon $/ 82 ; 3,265 / 87 ; 4$, FeII; $5,23 / 87 ; 6$, $17 / 87 ; 7$, Eldi $/ 80 ; 8,3.111 ; 9, \mathrm{~V} 75 / 93 ; 10$, $16 / 76$. The ECP were stained with rabbit antiserum to formalin-inactivated ECP of isolate $265 / 87$. The $20 \mathrm{kD}$ protein band is shown by an arrow

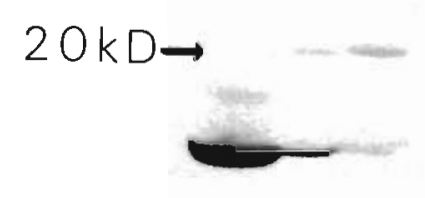

(Sheeran \& Smith 1981, Rockey et al. 1988) with a molecular weight of ca $22 \mathrm{kD}$ (Price et al. 1989).

Although the pathogenic role of the $\mathrm{P} 2$ protease is not known, the P1 protease is believed to play an important role in the pathogenesis of furunculosis
(Sakai 1985a, b). The P1 protease is toxic for yamabe Oncorhynchus masou f. ishikawi with an $\mathrm{LD}_{50}$ of 1.52 $\mu \mathrm{g} \mathrm{g}^{-1}$ body weight by i.p. injection (Tajima et al. 1983), and for Atlantic salmon at a dose of $2.4 \mu \mathrm{g} \mathrm{g}^{-1}$ body weight (Lee \& Ellis 1989). However, the major 
lethal toxin of Aeromonas salmonicida subsp. salmonicida appears to be glycerophospholipid:cholesterol acyltransferase complexed with lipopolysaccharide (GCAT/LPS) which has cytotoxic, haemolytic (T-lysin), and phospholipase activities (Lee \& Ellis 1990). The $\mathrm{LD}_{50}$ of the GCAT/LPS for Atlantic salmon by i.p. injection is $0.045 \mu \mathrm{g} \mathrm{g}^{-1}$ body weight (Lee \& Ellis 1990).

Neither haemolytic nor phospholipase activity was detected in ECP of Aeromonas salmonicida subsp. achromogenes strain $265 / 87$, but the purified extracellular metallo-protease isolated from the bacterium showed lethal toxicity for Atlantic salmon. The protease is a monomeric polypeptide in the native state with an $\mathrm{LD}_{50}$ of $0.03 \mu \mathrm{g} \mathrm{g}^{-1}$ body weight, more lethally toxic than either the P1 protease or the GCAT/LPS toxin of A. salmonicida subsp. salmonicida. This finding, and the lack of lethal toxicity of non-proteolytic fractions of ECP, would suggest that the $20 \mathrm{kD}$ protease is a major extracellular lethal toxic factor produced by this atypical strain.

In broth culture the protease appears early and the concentration is proportional to the cell number. It appears to be stable in the supernatant for at least $72 \mathrm{~h}$ of culture.

The mechanism of toxicity of the protease is not known. Although crude ECP of strain 265/87 was cytotoxic for RTG-2 cells, the purified protease did not show any detectable cytotoxicity. The absence of detectable haemolytic or phospholipase activity in the ECP suggests that the cytotoxin of strain 265/87 is not the same as that produced by Aeromonas salmonicida subsp. salmonicida (Lee \& Ellis 1990).

Five Aeromonas salmonicida subsp. achromogenes strains (isolated from salmonid fish in Iceland and the Faroe Islands) produced the $20 \mathrm{kD}$ protein, but this protein was not detected in ECP (possessing low or no proteolytic activity) of one Icelandic strain isolated from Atlantic salmon and 3 strains isolated from cyprinid fish in England, Yugoslavia and the USA. Inhibitor studies on proteolytic activity of strain $265 / 87$ and Fell, both possessing the $20 \mathrm{kD}$ band, showed significant inhibition by EDTA but the serine-protease inhibitor PMSF also had some effect. This would suggest the presence of a serine-protease in ECP besides the $20 \mathrm{kD}$ metalloprotease. Proteolytic activity of the other 3 atypical strains (Lon/82, 17/87 and Eldi/80), possessing the 20 $\mathrm{kD}$ band, was completely inhibited by EDTA but PMSF had no effect. The close correlation between extracellular metallo-protease activity, and the presence of a 20 $\mathrm{kD}$ protein in the ECP, suggests that this toxin is produced by other atypical strains (Table 4b, Fig. 6). ECP of the one typical strain (MTO04) tested, possessing high serine-protease activity, lacked the $20 \mathrm{kD}$ protein. There is a lack of evidence in the literature of any $A$. salmonicida subsp. salmonicida strain producing an extracellular caseinolytic $20 \mathrm{kD}$ metallo-protease and a well-defined strain of this organism (MT004) (Lee \& Ellis 1990), tested in this study, did not. Therefore it is possible that $A$. salmonicida subsp. salmonicida does not produce this lethal $20 \mathrm{kD}$ toxin. Further studies are, however, needed to confirm this. More studies are also needed to examine the frequency of this $20 \mathrm{kD}$ toxic protease among different $A$. salmonicida subsp. achromogenes strains.

Extracellular factors of $A$. salmonicida subsp. salmonicida have received considerable attention as possible protective antigens against furunculosis. Active immunization with crude ECP and protease, and passive immunization with antibodies to these preparations, have been reported to protect salmonid fish against furunculosis (Cipriano 1982, Olivier et al. 1985, Shieh 1985, Ellis et al. 1988c). It has also been reported that toxoids of crude ECP of an atypical strain could protect carp against erythrodermatitis, though the nature of the protective antigen(s) was unknown (Evenberg et al. 1988). If anti- $A$. salmonicida vaccines are to be developed based on ECP components, it is important to know if the protective antigens are shared by typical and atypical strains.

The potential role of the toxic protease of $A$. salmonicida subsp. achromogenes as a protective antigen against atypical furunculosis is currently being investigated.

Acknowledgements. This work was supported by the Icelandic Council of Science. We are grateful to Drs D. Evenberg and I. Dalsgaard for providing some of the strains used in this study.

\section{LITERATURE CITED}

Adams, A., Bundy, A., Thompson, K., Horne, M. T. (1988). The association between virulence and cell surface characteristics of Aeromonas salmonicida. Aquaculture 69: 1-14

Austin, B., Austin, D. A. (1987). Bacterial fish pathogens: Disease in farmed and wild fish. Elis Horwood Limited, Chichester, p. 111-195

Bradford, M. M. (1976). A rapid and sensitive method for the quantitation of microgram quantities of protein utilizing the principle of protein-dye binding. Analyt Biochem. 72: 248-254

Buckley, J. T., Halasa, L. N., MacIntyre, S. (1982). Purification and partial characterization of a bacterial phospholipid: cholesterol acyltransferase. J. biol Chem. 257 3320-3325

Cipriano, R. C., Griffin, B. R., Lidgerding, B. C. (1981). Relationship between extracellular growth products and isolate virulence. Can. J. Fish. Aquat. Sci. 38: 1322-1326

Cipriano, R. C. (1982). Immunogenic potential of growth products extracted from cultures of Aeromonas salmonicida for brook trout (Salvelinus fontinalis). Can. J. Fish. Aquat. Sci. 39: 1512-1518

Ellis, A. E., Hastings, T. S., Munro, A. L. S. (1981). The role of Aeromonas salmonicida extracellular products in the pathology of furunculosis. J. Fish Dis. 4: 41-51

Ellis, A. E., Burrows, A. S., Stapleton, K. J. (1988a). Lack of 
relationship between virulence of Aeromonas salmonicida and the putative virulence factors: A-layer, extracellular proteases and extracellular haemolysins. J. Fish Dis. 11. 309-323

Ellis, A. E., Stapleton, K. J., Hastings, T S. (1988b). The humoral immune response of rainbow trout (Salmo gairdneri) immunized by various regimes and preparations of Aeromonas salmonicida antigens. Vet. Immunol. Immunopathol. 19: 153-164

Ellis, A. E., Burrows, A. S., Hastings, T S., Stapleton, K. J (1988c). Identification of Aeromonas salmonicida extracellular protease as a protective antigen against furunculosis by passive immunization. Aquaculture 70: 207-218

Evenberg, D., Lugtenberg, B. (1982). Cell surface of the fish pathogenic bacterium Aeromonas salmonicida II. Purification and characterization of a major cell envelope protein related to autoagglutination, adhesion and virulence. Biochim. Biophys. Acta 684: 249-254

Evenberg, D., de Graaff, P., Lugtenberg, B., van Muiswinkle, W. B. (1988). Vaccine-induced protective immunity against Aeromonas salmonicida tested in experimental carp erythrodermatitis. J. Fish Dis. 11: 337-350

Fuller, D. W., Pilcher, K. S., Fryer, J. L. (1977). A leukocytolytic factor isolated from cultures of Aeromonas salmonicida. J. Fish. Res. Bd Can. 34: 1118-1125

Fyfe, L., Finley, A., Coleman, G., Munro, A. L. S. (1986). A study of the pathological effect of isolated Aeromonas salmonicida extracellular protease on Atlantic salmon, Salmo salar L. J. Fish Dis. 5: 403-409

Fyfe, L., Coleman, G., Munro, A. L.S. (1987). Identification of major common extracellular proteins secreted by Aeromonas salmonicida strains isolated from diseased fish. Appl environ. Microbiol. 53: 722-726

Hastings, T. S., Ellis, A. E. (1985). Differences in the production of haemolytic and proteolytic activities by various isolates of Aeromonas salmonicida. In: Ellis, A. E. (ed.) Fish and shellfish pathology. Academic Press, London, p. 69-77

Hastings, T S., Ellis, A. E. (1988). The humoral immune response of rainbow trout, Salmo gairdneri Richardson, and rabbits to Aeromonas salmonicida extracellular products. J. Fish Dis. 11: 147-160

Johnson, C. M., Tatner, M. F., Horne, M. T (1985). Autoaggregation and extracellular A-layer protein in Aeromonas salmonicida. Aquaculture 46: 163-166

Kay, W W., Buckley, J. T., Ishiguro, E. E., Phipps, B. M., Monette, J. P. C., Trust, T. J. (1981). Purification and disposition of a surface protein associated with virulence of Aeromonas salmonicida. J. Bacteriol. 147: $1077-1084$

Laemmli, U. K. (1970). Cleavage of structural proteins during the assembly of the head of bacteriophage T4. Nature, Lond. 227: 680-683

Lee, K. K., Ellis, A. E. (1989). The quantitative relationship of lethality between extracellular protease and extracellular haemolysin of Aeromonas salmonicida in Atlantic salmon (Salmo salar L.). FEMS Microbiol. Lett. 61: 127-132

Lee, K. K., Ellis, A. E. (1990). Glycerophospholipid:cholesterol acyltransferase complexed with LPS is a major lethal exotoxin and cytolysin of Aeromonas salmonicida. The LPS stabilises and enhances the enzyme's toxicity. J. Bacteriol. 172: 5382-5393

Mellergaard, S. (1983). Purification and characterization of a new proteolytic enzyme produced by Aeromonas salmonicida. J. appl. Bacteriol. 54: 289-294

Munro, A. L. S., Hastings, T S., Ellis, A. E., Liversidge, J. (1980). Studies on an ichthyotoxic material produced extracellularly by the furunculosis bacterium Aeromonas salmonicida. In: Ahne, W (ed.) Fish diseases. SpringerVerlag, Berlin, p. 98-106

Nomura, S., Fujino, M., Yamakawa, M., Kawahara, E. (1988). Purification and characterization of salmolysin, an extracellular haemolytic toxin from Aeromonas salmonicida. J. Bacteriol. 170: 3694-3702

Olivier, G., Evelyn, T P. T., Lallier, R. (1985). Immunogenicity of vaccines from a virulent and an avirulent strain of Aeromonas salmonicida. J. Fish Dis. 8: 43-55

Pol, J. M. A., Bootsma, R., Berg-Blommaert, J. M. (1980). Pathogenesis of carp erythrodermatitis (CE): role of bacterial endo- and exotoxin. In: Ahne, W. (ed.) Fish diseases: Third COPRAQ Session. Springer-Verlag, Berlin, p. $120-125$

Popoff, M. (1984). Genis III. Aeromonas Kluyver and van Niel 1936. In: Krieg, N. R., Holt, J. G. (eds.) Bergey's manual of systematic bacteriology, Vol. 1. The Williams and Wilkins Co., Baltimore, p. 545-548

Price, N. C., Stevens, L., Duncan, D., Snodgrass, M. (1989). Proteases secreted by strains of Aeromonas salmonicida. J. Fish Dis. 12: 223-232

Reed, L. J., Muench, H. (1938). A simple method of estimating fifty percent endpoints. Am. J. Hyg. 27: 493-497

Rockey, D. D., Fryer, J. L., Rohovec, J. S. (1988). Separation and in vivo analysis of two extracellular proteases and the T-haemolysin from Aeromonas salmonicida. Dis. aquat. Org. 5: 197-204

Sakai, D. K. (1985a). Significance of extracellular protease for growth of a heterotrophic bacterium, Aeromonas salmonicida. Appl. environ. Microbiol. 50: 1031-1039

Sakai, D. K. (1985b). Loss of virulence in a protease deficient mutant of Aeromonas salmonicida. Infect. Immun. 48: $146-152$

Sakai, D. K. (1985c). Efficacy of specific antibody against agglutinating Aeromonas salmonicida strains on infectivity and vaccination with inactivated protease. J. Fish Dis. 8: $397-405$

Sheeran, B., Smith, P. R. (1981). A second extracellular proteolytic activity associated with the fish pathogen Aeromonas salmonicida. FEMS Microbiol. Lett. 11: 73-76

Shieh, H. S., McLean, J. R. (1975). Purification and properties of an extracellular protease of Aeromonas salmonicida, the causative agent of furunculosis. Int. J. Biochem. 6: 653-656

Shieh, H. S. (1985). Passive protection of Atlantic salmon with rainbow trout antiserum to protease of a virulent strain of Aeromonas salmonicida. Microbios, Lett. 30: 13-17

Tajima, K., Takahashi, T., Ezura, Y., Kimuna, T. (1983). Studies on the virulent factors produced by Aeromonas salmonicida, a causative agent of furunculosis in salmonicidae-II. Studies on the pathogenicity of the protease of Aeromonas salmonicida Ar-4 (EFDL) on yamabe (Oncorhynchus masou f. ishikawai) and goldfish (Carassius auratus), and the substance which exhibits cytotoxic effect in RTG-2 (rainbow trout gonad) cells. Bull. Fac. Fish. Hokk. Univ. 34: 111-123

Tajima, K., Takahashi, T., Ezura, Y., Kimura, T (1984). Enzymatic properties of the purified extracellular protease of Aeromonas salmonicida. Ar-4 (EFDL). Bull. Jap. Soc. scient. Fish. 50: 145-150

Tasheva, B., Dessev, G. (1983). Artifacts in sodium dodecyl sulfate-polyacrylamide gel electrophoresis due to 2-mercaptoethanol. Analyt. biochem. 129: 98-102

Titball, R. W., Munn, C. B. (1981). Evidence for two haemolytic activities from Aeromonas salmonicida. FEMS Microbiol. Lett. 12: $27-30$

Trust, T. J., Howard, P. S., Chamberlain, J. B., Ishiguro, E. E., Buckley, J. T. (1980).Additional surface protein in autoag- 
gregating strains of atypical Aeromonas salmonicida. FEMS Microbiol. Lett. 9: 35-38

Udey, L. R., Fryer, J. L. (1978). Immunization of fish with bacterins of Aeromonas salmonicida. Mar. Fish. Rev. 40: $12-17$

Ward, P. D., Waters, C. A., Sweeney, K. J. (1985). Autoaggregation of virulent Aeromonas salmonicida strains lacking

Responsible Subject Editor: Dr T. Evelyn, Nanaimo, B. C., Canada additional surface layer. In: Ellis, A. E. (ed.) Fish and shellfish pathology. Academic Press, London, p. 107-117

Wichardt, U.-P. (1983). Atypical Aeromonas salmonicida infection in sea trout (Salmo trutta L.) 1 Epizootological studies, clinical signs and bacteriology. In: Salmon Research Institute Report, Alvkarleby, Sweden, 6: p. $1-10$

Manuscript first received: August 16, 1989

Revised version accepted: September 24, 1990 